\title{
CORRIGENDUM
}

\section{Ancestral whole-genome duplication in the marine chelicerate horseshoe crabs}

\author{
NJ Kenny, KW Chan, W Nong, Z Qu, I Maeso, HY Yip, TF Chan, HS Kwan, PWH Holland, KH Chu \\ and JHL Hui
}

Heredity (2017) 119, 388; doi:10.1038/hdy.2017.38; published online 9 August 2017

\section{Correction to: Heredity (2016) 116, 190-199; doi:10.1038/hdy.2015.89; published online 30 September 2015}

Following the publication of this article, the authors have requested that the wording in the Acknowledgements section be replaced with
'This study was supported by a Direct Grant (405303) of The Chinese University of Hong Kong. PWHH was supported by the ERC. We thank Stephen Smith of Virginia Tech for help supplying L. polyphemus samples.'

The authors apologise for any inconvenience caused. 